\title{
O maracatu, desde antigamente: narrativas e \\ atualizações de uma brincadeira da Zona da Mata de Pernambuco
}

\author{
Noshua Amoras de Morais e Silva \\ Graduada em Ciências Sociais , com
}

habilitação em Antropologia, pela Universidade de Brasília.

“Ah se o tempo voltasse atrás, ninguém mais brincava maracatu”, disse enfaticamente Dona Bibi enquanto conversávamos sobre o tempo antigo do maracatu, brincadeira existente em algumas cidades da Zona da Mata Norte de Pernambuco. Essa fala servia para arrematar sua constatação de que tudo aquilo que costumava acontecer e constituir o maracatu antigamente estava deixando de existir. É a partir do que disse Dona Bibi que desenvolverei este artigo, no qual apresentarei algumas questões suscitadas por meus interlocutores da cidade de Condado, folgazões (pessoas que brincam maracatu realizando performances corporais e musicais) de maracatu que conheci durante meu trabalho de campo realizado no ano de 2014 - e que resultou na minha monografia de graduação, defendida no Departamento de Antropologia da Universidade de Brasília.

O maracatu pode ser descrito como uma brincadeira quase exclusivamente do período carnavalesco ${ }^{1}$. Durante esses dias, é possível ver nas ruas, beiras de estradas e canaviais da região da Zona da Mata Norte de Pernambuco algumas das figuras do maracatu caminhando aparentemente sem destino certo. Além disso, os diversos grupos de maracatu se organizam para saírem no carnaval. Os folgazões se mobilizam para confeccionar fantasias e bandeiras bonitas, agregar uma boa quantidade de pessoas para brincarem em seus respectivos Maracatus, tomarem os devidos cuidados contra inveja e catimbós (formas diversas de causar malefícios), e, principalmente, fazerem boas manobras e evoluções durante os desfiles².

\footnotetext{
${ }^{1}$ O período carnavalesco é quando o Maracatu é posto na rua, mas em outros momentos ocorrem encontros de dois Maracatus, as chamadas sambadas. Há também, ainda que cada vez menos frequente, o maracatu de páscoa.

${ }^{2}$ As manobras e evoluções são os movimentos que todo o corpo do maracatu faz, realizando uma espécie de desenho no chão. Todos esses movimentos são guiados pela figura do mestre de caboco e realizados conforme a música tocada pelo terno (conjunto musical do maracatu).
} 
Logo, não é diferente com o Maracatu Leão de Ouro da cidade de Condado (PE), grupo com o qual fiz meu trabalho de campo. Durante os intensos dias de carnaval o Leão de Ouro desfila nas cidades da Mata Norte e nas passarelas do Recife, além de disputar com outros grupos o tão almejado título de campeão do carnaval recifense, tendo ganhado o título de campeão nos anos de 2012 e 2013.

Contudo, além de uma brincadeira carnavalesca, o maracatu pode ser também descrito como sendo do tempo antigo, ou apenas antigamente. Sobre isso os folgazões enfatizam sobre como a brincadeira era perigosa, pois ocorriam inúmeros enfrentamentos entre os diferentes Maracatus. Tais enfrentamentos podiam ser físicos ou ainda por meio de catimbós e requeriam dos folgazões cuidados e atenção permanentes. Entretanto, atualmente o maracatu tem perdido grande parte dessas características, na avaliação mesmo dos interlocutores, que dizem como desde o tempo antigo a brincadeira mudou consideravelmente. Dentre as várias mudanças apontadas, ora de forma positiva, ora negativa, algumas consistem no aumento dos enfeites das roupas e fantasias, o envolvimento de dinheiro, sua participação nos carnavais, diminuição de práticas de cuidado com relação aos catimbós, facilidades como transporte e alimentação.

\section{O maracatu, desde antigamente}

Como parte da rotina dos domingos, os homens estavam reunidos na sede. Sob o intenso e intermitente calor, todos, exceto eu, tomavam vodca com guaraná. Entre os mais diversos assuntos, se falava muito e quase sempre sobre maracatu. As informações sobre os Maracatus da região circulam entre as pessoas geralmente em tom de crítica, ainda que bem descontraído: onde aquele mestre estaria cantando agora, onde ele cantará no próximo ano, como ele consegue se promover; ou ainda, como aquele Maracatu de Fulano está em crise, quase para se acabar, e o de Sicrano estava desmantelado (bagunçado, desarrumado) no desfile do ano anterior.

A conversa se estende e começam a falar sobre como o maracatu era no tempo antigo e o tom se torna então menos jocoso. Pinone me diz que maracatu não tinha esse nome, era mulungu e não existia essa coisa de baque solto, isso é recente. Seu Biu, com a expressão séria, diz que "maracatu mudou muito" e completa: "Maracatu já tem dizendo no próprio nome, é ruim, é mal, Má - racatu, chama coisa ruim”. Derivan, levemente exaltado, o interrompe, dizendo: “eu discordo, Seu Biu!", e prossegue com a intervenção, "como é que pode uma coisa que foi resultado da aliança de negros e 
índios contra o senhor de engenho ser uma coisa má?". Seu Biu diz que Derivan, por ser ainda muito jovem, não alcançou o tempo antigo do maracatu.

Derivan têm por pouco mais de 20 anos, é folgazão desde muito tempo, e brinca de caboco no Leão de Ouro. Ele ainda fez menção de que iria retrucar em defesa de sua posição, mas Seu Biu continuou: "tem uma história que é verdade, tem uma testemunha viva para confirmar. Eu saía de casa sem saber se voltava, saía assim pelo mundo, dava um pulo pela janela e ia andando, eu chegava assim nos canto assim com a guiada nos dois ombros, cambaleando de fome, cansado. Por isso eu digo, se o maracatu fosse que nem antigamente metade desse povo aqui não saía!". Todos concordaram, e ele completou: "vocês não conhecem aquele cemitério lá por lado de Nazaré? O cruzamento lá das Bringas?”.

Durante a pesquisa ouvi inúmeras histórias de como o maracatu foi algo violento, que trazia no seu rastro a própria morte. Mas os folgazões, longe de confirmarem ou negarem com exatidão esses fatos, narravam diversas histórias de acordo com o que tinham vivido ou ouvido. Dentre tais narrativas, confirma-se somente que há um lugar nas redondezas de Condado que testemunhou o porquê do risco de "não voltar para casa": o cruzamento das Bringas, encruzilhada localizada no antigo e desativado Engenho do Bringa, onde os cabocos, em época de carnaval, quando "nem existia maracatu”, deveriam passar e ao se encontrarem travavam batalhas que poderiam acarretar sérios ferimentos ou mesmo mortes.

O tempo antigo do maracatu pode ser entendido de diversas maneiras. Na bibliografia do tema, por vezes ele é abordado como o tempo sagrado da brincadeira, no qual se praticava em maior extensão cultos religiosos ligados à Jurema³, ou quando os Maracatus não haviam se deslocado do contexto rural para o urbano e começado a participar dos carnavais oficiais do Recife (Sumaia, 2012; Sena, 2012). Entre os folgazões, há ainda outras considerações sobre o que vem a ser o maracatu nesse tempo antigo e que envolvem uma constante referência a um tempo de conflitos e enfrentamentos acirrados.

Convivi com alguns velhos folgazões de maracatu. Destes, destaco em ordem de idade, Seu Martelo, Seu Biu Alexandre, Zé Mário, Seu Ramiro e João Pererê. Martelo é o mais antigo destes folgazões; tendo um pouco mais que 80 anos, ele precedeu e por vezes ensinou muitos dos demais,

\footnotetext{
${ }^{3}$ A Jurema é um culto bastante presente na extensão da região nordeste, tem uma "religiosidade que engloba em si diversas tradições" e faz referência "a um campo maior e mais fluido de seres desencarnados" de mestres e mestras, caboclos, pombasgira e exus, podendo ser praticado de diversas maneiras "sem necessariamente compor um corpo doutrinário bem delimitado" (Stoeckli, 2010: 1).
} 
hoje entre 70 e 80 anos. Estes senhores viveram uma mesma época do maracatu, que estimo sendo do final da década de 30 e início da década de 40, convivendo com ele desde a infância.

Para João Pererê, por exemplo, o maracatu veio de berço, seu pai já era folgazão. Sua fama em Condado é a de um caboco do tempo antigo e bom de pau (habilidoso nos enfrentamentos), por isso fui procurá-lo. Ele não sai mais em nenhum Maracatu, não porque tenha passado da idade, mas sim porque seu estado de saúde não lhe permite, pois sente fortes dores na coluna. Para ele, o maracatu de antigamente é muito diferente do de hoje, quando "todos [es]tão ricos", andando apenas de carro e voltando para casa todos os dias, ninguém mais briga, não teria mais a "ignorância”. Ele explica:

Naquele tempo era da ignorância. Já ouviu falar no Cruzeiro das Bringa? Antigamente, que todos os brinquedos de Pernambuco: bloco, maracatu, cabocolinho, tinha aquela obrigação de passar lá. E ali era pra briga, naquele negócio era pra brigar ${ }^{4}$. Tinha tanto caboco enterrado com guiada, chapéu. Não tinha esse negócio da família levar pra fazer enterro não. Naquele tempo, os pais de família - os cabocos - se despedia da mulher, de filho. Não sabia se chegava vivo ou morto, tinha que se despedir. Antigamente caboco era nesse pisada, nessa pisadinha5. Brincava domingo, segunda, terça, as vezes chegava na quarta-feira de cinza já amanhecido. No tempo da ignorância ó, vamos dizer assim: fulano mora aqui, eu moro ali, quando é no sábado de Zé Pereira, eu digo, 'Fulano, tu vai sair de que horas? Seis horas? Tá certo', ai quando dava quatro horas da madrugada, eu já tava me ajeitando pra tucaiar [espiar] a saída dele. Quando dava cinco horas já tinha tomado café, me ajeitado, ia pra porta dele tucaiar ele. De 50 anos atrás, a pisada era esse. Ou se abraçava ou não saía mais. Sabia que na frente ia encontrar tocaiada mais pesada que aquela. A pisada era essa. Um caboco se encontrava com outro... Na má intenção. Botava bico de ferro na ponta da guiada. Naquele tempo era assim, quando se encontrava era a malícia, o pau trovejava 6 . Muito caboco adoecia, caia, levava cacete, de pau, guiada, era de tudo. Não tinha isso de dizer eu fui bonzinho. Botava aquele cravo na boca assim,

\footnotetext{
${ }^{4}$ Além das brigas entre os Maracatus, Fabinho comentou ter ouvido dizer que havia brigas entre Maracatus e Cabocolinhos (uma brincadeira da região na qual todas as pessoas vestem-se de índios), e nessa briga, disse-me ele, os Maracatus em geral perdiam, pois "os índios dos Cabocolinhos eram mais bravos".

${ }^{5}$ A pisada, ou pisadinha, sobre a qual Seu Pererê fala se refere ao "jeito", ou "maneira", do andar de cada caboco. Mas não somente isso, o "jeito" desse andar implica na habilidade de um caboco em movimentar-se habilmente, com passos e movimentos precisos, porém discretos, tanto para que outro caboco não o perceba se aproximando, quanto para que seus movimentos consigam persuadir ou enganar. Naquele tempo, essa pisada era mais habilidosa e causava mais brigas.

${ }^{6}$ No tempo antigo, era frequente o pau trovejar, isto é, quando dois cabocos se enfrentavam, os choques entre as suas guiadas provocavam barulhos extremamente altos.
} 
existia cravo $^{7}$. Na chegada em barraca [sede de cada Maracatu] cada um queria ver a chegada do caboco. Mestre de caboco que não fosse bom pra fazer chegada [manobras individuais] $e$ caboco né... Aí os outros diziam que a chegada era feia. Era cacete e andava de pé. Só brincava quem tinha coragem." (João Pererê, Agosto de 2014).

Já Seu Ramiro discorda de que nos tempos antigos se matava e morria em brigas no maracatu, conforme disseram Seu João Pererê e Seu Biu. Ele diz não acreditar que as brigas e mortes tenham acontecido ou aconteçam no maracatu e enfatiza que quando elas ocorrem, é por fatores como desentendimentos pessoais, excesso de bebidas alcoólicas e etc. Para ele o maracatu sempre foi na malícia, isto é, na intenção de se atingir e enfraquecer um Maracatu ou caboco rival através da mundrunga, da macumba e da mandinga, do Santo Heleno e do São Cipriano.

Mundrunga e macumba, e ainda catimbó e feitiço, nomeiam, para Seu Ramiro, coisas similares: aquilo a que se recorre para atacar ou defender-se de algo e que pode ser acionado por meios diversos (centros ou em casa, caso se saiba manejar objetos dessa ordem, rezas e etc.). Não consegui maiores informações sobre as diferenças entre essas quatro categorias de malefícios. Até onde pude entender, a macumba está mais ligada às coisas feitas (ou que se supõe serem feitas) em centros de Jurema; mas, de toda forma, a categoria que parece englobar as demais, sendo utilizada com mais frequência, é a do catimbó. Já a mandinga, além de provocar efeitos maléficos, está intimamente ligada à malícia, em especial no que diz respeito aos folgazões de maracatu.

Diz-se com frequência que um caboco mandingueiro é aquele que possui grandes habilidades para manusear e tirar proveito dessas práticas, seja se protegendo, seja atacando outros folgazões e Maracatus. Alguns desses cabocos, diz-se,

Fazia preparado mesmo. Tinha um ali em Itaquitinga que a guiada dele corria água na ponta e quando ele [a]tacava um, caia cinco [cabocos adversários]. E Fulano de lá do Maracatu tal, ele dava uma tacada, ele saia com cinco braço [de altura] assim, caia aqui em pé. E o Sicrano de Catanduba? Ele ia bater pau mais você, a sua guiada virava uma cobra. Ele comprava dois par de sapato pra brincar domingo [de carnaval], quando dava dez braça [de distância] pra chegar no terreiro, ele se avoava nos ares! Quando plantava no chão, o sapato descolava, ai vinha o

\footnotetext{
${ }^{7} \mathrm{O}$ uso de uma flor de cravo na boca ainda existe entre os cabocos. Entretanto, boa parte deles utiliza flores artificiais. Durante o trabalho de campo, não ouvi tantas menções sobre o cravo, apenas que alguns folgazões os calçam (em geral levam a algum centro de Jurema) antes do carnaval. De toda forma, insiste-se no fato de que esses cravos não são os mesmos que os de antigamente, quando as flores eram de verdade e tinham a finalidade de proteger os folgazões.
} 
filho pequeno dele e dava o outro sapato pra ele. E guiada dele, ele batia pau mais outro... sustente seu cacetinho meu filho! Ran! Quando pensava que não, quando ele botava três vezes, a guiada do cara virava uma cobra, saia da mão do cara e ficava nos ares e o cara ficava desarmado. (agosto de 2014).

Santo Heleno e São Cipriano são famosos por ali; não foram raras as vezes que eu ouvi seus nomes, em especial o do segundo. Mas, apesar de carregarem os nomes de santos, nunca os ouvi sendo relacionados à Igreja Católica. Variando substancialmente nas formas que são mobilizados, a mais recorrente entre os folgazões é a utilização dos santos carregando-os (pelo que pude entender, trata-se de suas imagens em papel, os "santinhos") de cabeça para baixo, ou invertidos de alguma forma, em uma pequena bolsa que se carrega consigo ou próximo a qualquer parte do corpo. Ao serem utilizados, eles permitem que seus portadores tenham o corpo fechado, estando protegidos de quaisquer males e perigos, sejam eles visíveis (brigas, arma de fogo, facas e etc.) ou invisíveis (espíritos ruins, macumbas) ${ }^{8}$.

Seu Ramiro diz que por meio da malícia, da mundrunga, da macumba e da mandinga, no tempo antigo se fazia uso com mais afinco de práticas que desestabilizavam os Maracatus e cabocos rivais. Estes eram os meios centrais aos quais se recorria como arma para atacar esses possíveis inimigos; eles provocariam males, como cegueira e fraqueza nos cabocos de um Maracatu adversário. Poderia ainda acarretar em desmantelos (erros e desorganização) durante o carnaval, quando uma série de pequenos acontecimentos, aos poucos, atrapalhassem um dado grupo. Era esse o foco da rivalidade e conflito do maracatu:

Hoje todo maracatuzeiro e todos caboco fala: sou isso, sou aquilo. Não é o mesmo caboco, porque era os caboco antigo [que] só brincava no catimbó. Se você, no domingo de carnaval, de manhã bem cedo não tinha energia, na porta da madrugada você perdia o estandarte [bandeira do Maracatu]. Só no catimbó. Você queria sair de casa você não podia, não acertava nem com a porta, seus olhos inchava. Tudo no catimbó. Tinham esses caboco...” (Seu Ramiro, agosto de 2014).

Mas não foi somente Seu Ramiro quem ressaltou para mim das mandingas no maracatu.

\footnotetext{
${ }^{8}$ Por vezes, a distinção entre Santo Heleno e São Cipriano é a de que o primeiro é preto e o segundo branco. Diz-se também que são Cipriano é um livro, o Livro de São Cipriano, que contém toda sorte de feitiços e bruxaria. Ouvi menção a esse livro diversas vezes, cada uma delas oferecia uma nova forma de utilizar do santo, ou do livro, e dos poderes que ele tinha (ficar invisível, fazer chover, e etc.).
} 
A temperatura em Condado estava alta, a sensação de abafado sinalizava possível chuva, de modo que a dor na perna esquerda de Seu Martelo se intensificava. Ele disse, contudo, que daquela vez os remédios estavam fazendo efeito. A outra perna de Martelo também é doente, ela "deu problema" na primeira vez em que ele saiu no carnaval de Mateus em um Urso9. Como de costume, ele brincou os três dias seguidos e, na terça-feira de carnaval, quando retornou para casa, foi acometido por essa dor que durou noventa dias e que somente passou com a ação de um grande rezador, qualidade que segundo ele, hoje em dia não se encontra mais. "E o senhor sabe de alguma dessas rezas?", perguntei a ele, que me respondeu: "Sei nada, isso é tudo coisa do livro de São Cipriano. Quem quer aprender as rezas desse livro tem que ir na casa da pessoa [que possui o livro] durante três dias à noite e no quarto dia tem que encontrar uma cabra preta no caminho”, "E o senhor já encontrou?", lhe indaguei, que prontamente me respondeu na negativa, e completou: "mas já fui no inferno..."

Seu Martelo é um caboco já parado (não brinca mais em Maracatu algum). Ele é um homem negro, magro e que aparenta ter sido em sua juventude mais forte do que é hoje, o que não lhe impede de passar madrugadas em sambadas de maracatu e brincando de Mateus no cavalo marim Estrela de Ouro. Sua idade também faz dele um exímio colecionador de histórias.

$\mathrm{Na}$ "casa de fuxico" que é o maracatu, como me disseram certa vez, não são somente comentários e fofocas sobre os outros grupos que circulam entre os folgazões. Fala-se também sobre as qualidades, ou defeitos, dos cabocos; se eles são habilidosos, se sabem das coisas do tempo antigo e, principalmente, se são mandingueiros. Nesse sentido, existe a história de que Seu Martelo é um dos únicos cabocos vivos que já foi ao inferno. História essa que ele não somente confirma como enfatiza que isso já ocorrera três vezes, mas que ele só entrou mesmo no inferno em uma delas. Ouvi ainda outro rumor de que em uma dessas idas ao inferno ele encontrou vários cabocos conhecidos em vida e que já estavam falecidos, todos com suas arrumações (fantasias), segurando, todos juntos, uma guiada de mais de 10 metros de comprimento.

"Eu já fui no inferno" repetiu ele, enquanto fechava os panfletos das apresentações que já fez pelo Brasil e que havia retirado para mostrar-me. "Se você quiser eu levo você lá, só não ensino a voltar...” Dispensei o convite. Ele conta que um dia estava dormindo na rede quando era pequeno e, de repente, caiu, já dentro do inferno. Perguntei-lhe como era lá, e ele me contou: "É um engenho o

\footnotetext{
${ }^{9}$ Outra brincadeira da região, menos frequente que o maracatu e cavalo marim, que é posta na rua durante a época carnavalesca.
} 
inferno. Tem tudo que tem aqui: casal que dorme junto, apelido assim que nem a gente dá, moinho, cana de açúcar"ıo. Ele narra como caminhou por bastante tempo dentro do engenho-inferno. Ao passar pelo moinho, encontrou um portão onde lhe ofereceram cachaça, ele recusou. Mais a frente, quando encontrou um lago, ao tentar atravessá-lo caiu novamente em sua rede. No mesmo instante a rede arrebentou e ele caiu no chão, "com as mão e braço estendido, assim formando uma cruz". Seus pais lhe foram de encontro e sua mãe, já sabendo o que fazer, rapidamente pegou uma bacia d' água e o molhou do tronco para cima e depois o inverso; foi assim que ele pode "voltar".

Com Seu Martelo, o silêncio era pouco constrangedor pois, nesses intervalos, eu imaginava as histórias que ele sempre contava. Depois de alguns minutos ele completou: "E foi no inferno também que se criou o maracatu!". "Mas tinha maracatu quando o senhor foi lá?”, "tinha não”, ele responde, “era tempo de São João, aí não tinha não...”. “Como assim Seu Martelo?”, eu perguntei empolgada, mas aí ele já havia começado a contar outra história sobre o “começo do século”, no tempo em que os bichos falavam ${ }^{11}$.

Em outra ocasião, ainda na casa de Seu Martelo, Derivan comentou sobre uma história que ele ouvira, da habilidade e rapidez de um caboco que lhe permitia sumir e reaparecer em poucos segundos: "A gente vivia lá naquele maracatu e Fulano e ele falava de João. Armaram uma boca de trincheira e colocaram oito caboco lá. Fulano disse: toca o terno! Lá vem João, pei pei pei. Oxe, só via a poeira, ele já tava do outro lado, do lado de Fulano...ninguém viu”. Dona Bibi, que ouviu a história da cozinha onde preparava o almoço, comenta de lá mesmo: "E tem nada demais nisso? Aaaah, isso é pouco pra maracatu!".

Até então a esposa de Seu Martelo havia permanecido em silêncio, tendo ficado na cozinha enquanto conversávamos na sala. Dona Bibi é uma comunicativa senhora que deve ter a mesma estatura do marido, mas aparenta ser mais forte que ele. Ela, impacientemente, vem da cozinha ao que parece com o objetivo de nos esclarecer tudo, dizendo que essas “coisas de assombração" não existem mais no mundo, já existiram, mas hoje em dia não mais. Pensei que Dona Bibi iria contradizer todas as histórias que ouvi sobre maracatu, inclusive aquelas contadas por seu marido.

\footnotetext{
${ }^{10}$ Nesse sentido, ouvi de outra pessoa o comentário de que o inferno é um engenho de cana-de-açúcar e o Diabo é alvo (branco) que nem o senhor de engenho.

${ }^{11}$ No começo do século, os bichos falavam, conversavam entre si e eram feirantes: o pavão, a galinha, a raposa, o cachorro e o gato, cada espécie era responsável pela venda de um produto, o urubu pela goma [de mandioca], a raposa pela carne seca, o gato era o bodegueiro e o cachorro o aquele que bebia e pagava fiado. É interessante notar que os brincadores do Nove com os quais Martins (2013) realizou sua pesquisa, dizem que no "começo dos séculos" a conversa era, como coloca a autora, irrestrita, e dela participavam pessoas, animais, plantas, corpos celestes.
} 
Contudo, contradizendo o que acabara de dizer instantes antes, a senhora prosseguiu com a fala, explicando que, apesar disso, o maracatu permanece com as suas próprias necessidades e cuidados, por exemplo, a necessidade que cada caboco tem de buscar - em algum lugar que não especificou - o som do chocalho (surrão). Caso não o faça, o surrão será para sempre rouco (não emitira um bom som).

A fantasia de um caboco é bastante complexa. Anualmente, os folgazões fazem seus chapéus, enfeitam suas guiadas com fitas e tecidos, e bordam, ou mandam alguém bordar, suas golas. Sob a gola está o surrão, uma espécie de grande sino, um conjunto deles - cerca de seis a oito (quanto maior o surrão, maior o prestígio do caboco) - que é pendurado nos ombros e carregado nas costas durante todo o carnaval, emitindo sons na medida em que os cabocos se movimentam. Esses sons somente serão ouvidos a alguma distância, segundo Dona Bibi, se o caboco o tiver buscado logo quando começou a brincar.

Uma vez buscado o som do surrão, o objeto não dever ficar muito tempo parado. Isto é, quando um caboco morre ou deixa de brincar, por qualquer que seja o motivo, após alguns carnavais encostados o surrão começa a bater sozinho. Sobre isso, Dona Bibi explica:

Chega janeiro, o carnaval é fevereiro ou março. Fevereiro começa a bater, bate um dia só, de meio-dia, numa outra semana com quinze dias, bate de seis horas da noite. Aí pronto. Quando dá quinze dias de novo, pra acabar o mês, dia 3o, de dia e de noite, qualquer hora, seis horas da noite, bate de novo. Aí pronto! Quando entra o mês do carnaval bate uma vez só, bate uma vez. Aí pronto! Quando chega, tem as datas, dia 1, dia 15, dia 30, tem que bater sete vez. Agora, só da três pancada. Na primeira vez que eu vim morar com Sebastião eu era besta, não sabia o que era caboco, não sabia o que era nada, não conhecia de nada. Só sabia de cozinha, panela e tomar conta de menino. Bastião foi numa cerca pegou um bocado de arame amarrou o chocaio [surrão] sozinho, trabalhava na [Usina] São José. Fique sentada na porta da cozinha. Daqui a pouco ouvi aquilo: bateu. Aí eu fiz assim: quem é que tá ai meu filho, mexendo nas coisas do teu pai? 'Aqui tem ninguém não', ele respondeu. Ai eu perguntei a Cumpadre Luiz que hora é? 'É meio dia'. Bateu o chocaio. Também não tive medo não. Fui na casas de mãe e disse: o mãe, o chocaio de Bastião bate. Ela disse: 'tu não viu nada ainda, tu ainda vai ver coisa'. Meus deus do céu, num diga nada não, não tinha medo não. Minha filha, quando deu seis horas da noite, deu o café aos meninos, me sentei. Entrou um homem dentro de casa que eu nunca vi na minha vida 
nem ei de ver mais nunca. Dessa grossura, daqui pra baixo. Com a cabeça pequenininha, não sei como ele passou na porta. Pegou o surrão, pa pa pa pa pa pa pa pa. Balançou. E eu com o olho fechado e os meninos tudo assentado nos tamburetinho. Agora, dentro de casa ninguém via, só quem via era eu. Ele balançou bal bal bal, colocou no lugar. Me arrepiei todinha. Aí vai eu pego os meninos, vou. Quando eu chego na casa de Dona Santa [juremeira], ai lá vem um cachorro, cachorro branco, lá vem o cachorro, lá vem o cachorro. Será que ele vai me morder? Ele chegando perto de mim e eu chegando perto dele, mamãe disse que eu não tivesse medo, e lá vem, lá vem, lá vem. Quando eu cheguei no terreiro da mulher que era espírita, que eu fazia o calço [calçar o corpo/fechar o corpo] dele, o cachorro chegou, e o cachorro foi o mesmo homem que passou e entrou dentro da minha casa. Ai ele foi: 'viesse fazer o que aqui?' Os menino botou pra gritar, ela deu um sopro no meu ouvido, mandou eu vim embora pra casa. Ai Dona Santa disse que isso aí é pra você contar o que você viu pra todo mundo que quiser contar na verdade e acreditar no que você viu. Tem muita gente que diz que vê o surrão batendo, mas nem todo mundo vê. Eu vi porque eu tava grávida." (Dona Bibi, Agosto de 2014).

Entretanto, tanto sobre o surrão quanto sobre as outras práticas que envolvem a mandinga, era frequente que até cabocos mais velhos refutassem a existência de tais comportamentos, regras e eventos. Outra história bastante conhecida, mas igualmente refutada por boa parte dos folgazões, é sobre o tempo em que se pulava a janela: ao sair para o carnaval, os cabocos não deixariam suas casas pela porta da frente; eles o fariam pulando de costas pela janela. Todos comentavam que na época em que se faziam "essas coisas", no tempo antigo, as fantasias eram mais maneiras, ou seja, menores e mais leves, e talvez possibilitassem esse feito. Mas Seu João Pererê, por exemplo, afirma que "essa história de pular a janela é falsa".

Contudo, Seu Pererê disse-me que havia somente uma possibilidade de se pular a janela: sendo um caboco invisível. Ao ouvir isso, pensei ser mais uma de suas piadas e tive meu riso interrompido por sua expressão séria - que parecia não entender onde eu vira qualquer graça. Interrompido meu riso, ele continuou:

Aconteceu comigo num sábado de páscoa. Aí dia de sábado, dez horas do dia, eu digo: vou lá em Vitória. Vou por aqui, pego aquela Chã do outro lado de Canoa, vou lá...Desci pra lá, desci.

\footnotetext{
${ }^{12}$ A gravidez e o resguardo (o pós-parto) são momentos que demandam bastante atenção e cuidado. Durante a gravidez, caso a mãe ouça o bebê chorar dentro da barriga, saberá que isso indica que ele será portador de alguma mediunidade ou poder dessa ordem. O cuidado com o resguardo é ainda mais fundamental. Nele, a mãe não pode levar qualquer susto ou passar por alguma raiva, isso poderá afeta-la fisicamente, causando-lhe "dor no osso" e grande sensibilidade ao frio.
} 
Cheguei ali no bar do Vado, desci por ali, peguei aquela mata descendo. Quando passei o primeiro sítio, quando cheguei ali, embaixo na beira do rio, aí eu descendo... ele de lá pra cá, pra encontrar comigo, lá vem, lá vem, tin tin tin tin tin o chocaio. Ai eu desci, quando eu desço, lá vem ele. Aí quando chegou, antes de chegar no pé da ladeira, tem uma ponte, aí quando foi chegando no pé da ladeira, chegando na ponte, e eu vendo ele assim, chapelão bem grande, de crepom, todo vermelho. Lá vem, lá vem, lá vem. Aí lá vem. Quando ele chegava perto da ladeira, eu tocaiando, tem uma ponte, eu vinha chegando quase no pé da ladeira, quando eu balancei a cabeça assim, que eu fiz assim, não vi mais nada. Não vi mais nadinha. Na cabeça da ponte. Ai eu fiz assim, quando eu olhei pra frente não vi mais nada. Me arrepiei todinho. Passei, quando saí, pei pei pei, quando cheguei lá do outro lado da ponte eu sinto aquele quenturão, parece que [ele] evaporou assim. Sai na ponta do pé, tin tin tin tin... quando vou lá na frente mais ou menos umas vinte braças, que olho pra trás, ele ia subindo a ladeira, de lá pra cá! Oxeeen, olhei assim, oxeen, subindo a ladeira, ele passou por onde?! Aquele quenturão foi quando eu passei por ele. Quando eu andei uns vinte braços, quando olhei pra trás o caboco subia com toda pilha, o caboco ia subindo tin tin tin, pra chegar na mata. Vim m'embora. Ai fiquei naquilo, dizendo ao finado Mané Betinho, ele chegou disse a mim: a pois todo ano aquele caboco passa ali. Ele me disse o nome do caboco e eu me esqueci. Ai eu cheguei assim, mas rapaz. Mas eu vi essa vez só. (João Pererê, agosto de 2014).

Sem maiores delongas sobre o que seria ou que possibilitaria a ação do caboco invisível, Pererê já havia mudado de assunto enquanto eu imaginava a cena por ele narrada.

Após ouvir tantas narrativas sobre o tempo antigo do maracatu e de seu extremo perigo, resolvi perguntar a Seu Pererê se o maracatu era ruim ou bom. Ele me respondeu que era do bem, era sim uma coisa boa. Entretanto, Ivanice, uma de minhas principais anfitriãs em Condado, o interrompeu, reformulou a questão e perguntou assertivamente: "O que ela quer saber é se maracatu é da parte de Deus?", o que Pererê responde com a expressão séria, "Não. Deus deixou tudo no mundo, mas não deixou o maracatu”.

\section{Considerações Finais}

Além de brincadeira do tempo antigo, o maracatu, para alguns folgazões, não está ao lado de tudo aquilo que fora criado por Deus. Ele, inclusive, está presente no inferno (em alguns períodos do ano), como disse Seu Martelo. Brincadeiras do tempo antigo podem ser criações de Deus ou do 
Diabo, como mostra Martins (2013) sobre o Nove mineiro ter sido criado por Deus, já que dele todas as pessoas podem participar. Chaves (2011) também trata da autoria de brincadeiras como sendo do Diabo ou de Deus. No caso específico do cavalo marim e maracatu, ela mostra como essas duas brincadeiras se opõem na medida em que a primeira é criação de Deus, e a segunda do Diabo. A narrativa que diz ser o maracatu da autoria do Diabo foi registrada pela autora, contada para ela por Martelo por ocasião de sua pesquisa:

'Maracatu não pertence a Deus não. Maracatu pertence ao diabo. O diabo foi quem fez o Maracatu. Fez uma festa de três dias. O Maracatu começou assim: o diabo passou e viu Nosso Senhor dando a medicina aos dotô, que vive nos hospital e posto de saúde. Quando chegou à terra dele (do diabo) que tinha o patrão dele (disse): 'eu vi o senhor do povo dando a medicina aos dotô e eu achei bonito. Que a gente faz?' Ele disse: 'Vamo fazer uma festa de 3 dias. Faz a festa e vai chamá ele (NS) [Nosso Senhor]. Em cada beco de rua a gente bota 2 vigias.' (o Diabo): 'A gente vai fazer uma festa de 3 dias o Senhor vai?' ele (o Senhor) disse: 'vou'. Em todos os 3 dias NS foi: no domingo, na segunda e na terça, quando foi na quarta ele (o Diabo) chegou: 'cadê você eu não lhe vi'. Em cada beco de rua tinham botado 2 vigias pra pegar Nosso Senhor, mas não tinha podido pegar. Eles atentaram Nosso Senhor na quarta feira da cinzas até na sexta feira da paixão, botaram os judeus pra pegar Nosso Senhor na virada e pegou, né? Quando foi domingo de páscoa fizeram Maracatu, fizeram carnaval, pra ver se Nosso Senhor tava aqui na terra. Ai ficou o Maracatu." (Martelo)' (Chaves, 2011: 69).

Para a autora, essa narrativa mítica inverteria temporalmente o calendário cristão: o Carnaval se inicia no Domingo de Carnaval e termina no Domingo de Páscoa - já que os "caboclos de lança" seriam os judeus perseguindo Nosso Senhor durante a Quaresma, e o Domingo de Páscoa, a data em que se comemorava o sucesso da perseguição. Assim, os três dias de carnaval seriam a representação da perseguição a Cristo, implicando um regime de seriedade, respeito e abstinência sexual, e a Páscoa, sendo a comemoração, implicaria no real carnaval no qual os "caboclos" não teriam os mesmos compromissos e seriedade de durante o carnaval (idem: 69) ${ }^{13}$.

\footnotetext{
${ }^{13}$ Durante o meu campo não foi possível acompanhar qualquer atividade do maracatu de Páscoa. De toda forma, naquele ano, os cabocos que eu conheço não saíram nessa época. No maracatu de páscoa, nenhum maracatu é posto na rua, o que acontece são cabocos, em pequenos grupos ou sozinhos, que vão bater surrão. Seu Pererê me disse que “Carnaval de páscoa é o carnaval mais perigoso que tem, quando a pessoa vê qualquer maleficio ruim. É melhor a pessoa brincar sempre carnaval, de que [ao
} 
A autora ressalta também que a rivalidade é importante para pensar a constituição do maracatu, e assim diz sobre o Diabo indicar uma "inconformidade com os limites (terrestres, corporais, naturais), tendo como guia a expressão da rivalidade", que configuraria explicitamente a disputa como foco de existência do maracatu, tanto na sua narrativa de origem, entre Deus e o Diabo, quanto nos enfrentamentos contemporâneos dele (disputas nos concursos) (idem: 73).

Era intrigante a forma como cada pessoa contava e reagia às histórias de mandinga no maracatu, tais como as idas ao inferno, as guiadas que se transformavam em cobras e cabocos invisíveis. Quando indagadas por mim sobre qualquer que fosse o assunto que envolvesse isso, em certos casos ou não se tinha ciência do assunto ou o caso em questão havia acontecido com outrem. Por outro lado, por vezes, o que me pareciam histórias fantásticas, "sobrenaturais”, eram recebidas pelas pessoas com a mais ordinária indiferença.

Nesse sentido, sobre as histórias contadas pelos folgazões do perigo e da mandinga, destaco o fato de que não é que todos eles tenham conhecimento ou façam uso de práticas mandingueiras. Seu Pererê não sabia explicar muito bem o que permitira que aquele caboco ficasse invisível e sumisse no ar. Contudo, pouco importa para ele tal explicação, o que é significativo é que sempre existe a possibilidade de isso acontecer. Ou seja, novos eventos e acontecimentos, ainda que outrora desconhecidos ou por vezes impensáveis, tornam-se possíveis diante da experiência do maracatu e são significados a partir das possibilidades de eventos que existem nele.

A fonte de poder do maracatu, ou das condições extraordinárias de suas possibilidades, é o tempo antigo. Por mais diverso que seja esse tempo, ele está presente no que constitui a brincadeira. Vê-se então que o tempo antigo diz muito sobre o começo do maracatu, porém ele versa muito menos sobre quando o maracatu começou, e mais sobre como ele era e o que ele fazia. Dessa forma, o que os folgazões trazem não é tanto uma explicação sobre a gênese da brincadeira e sim uma narrativa mítica, na medida em que se refere ao estabelecimento de coordenadas espaço-temporais e das condições do mundo experienciado no presente.

O interessante a ser notado é que sempre existe um tempo ainda mais anterior ao que está sendo contado e a quem está contando. Sendo indicado a mim como uma pessoa do tempo antigo, Seu Pererê diz que não alcançou esse tempo do jeito que ele era de fato, e indicou que eu conversasse com Martelo, que por ser mais velho saberia de tais coisas. Quando me indicavam sobre

invés do] o de pascoa, é mais perigoso, só é cachaça, bagunça, encrenca. Só sai os caboco sozinho. É difícil ver maracatu completo." 
quem eu deveria conhecer e conversar sobre maracatu, o critério utilizado para tais escolhas era de folgazões que fossem do tempo antigo, pessoas como Seu Biu, Seu Ramiro e Seu Caju. Esses três, por sua vez, contaram diversas histórias de maracatu, mas apontaram, no final, que estas haviam ocorrido em um tempo antigo não alcançado por eles em sua plenitudade, mas acessado apenas por intermédio de seus pais e colegas mais velhos, como Martelo. Para Martelo, ele teria vivido apenas o final desse tempo, tendo alcançado tudo o que ocorria já em menor intensidade.

O que Seu Biu, Seu Ramiro, Martelo, Pererê e Dona Bibi contam sobre o que constitui de fato o maracatu, está em seu passado, expresso no que ele costumava fazer, mas que não faz mais - seja sobre o perigo das violentas brigas entre os cabocos e os Maracatus, seja no perigo das mandigas e mundrungas, ou ainda da criação do maracatu pelo Diabo. A relação entre esses diferentes efeitos do maracatu e a maneira como os folgazões o narram mostra que ele faz alguma coisa hoje, precisamente, porque antes ele fazia mais ou menos outra coisa, ou seja, a existência dele no presente está ligada ao que ele tinha no passado.

O regime temporal desse mito contado pelos folgazões mostra que há sempre uma espécie de “ponta solta” deixada: alguém viveu, ao menos, o final do tempo antigo. Alguém ter vivido esse final aponta, ainda que residualmente, para a potencialidade daquilo que era feito no tempo antigo voltar a ser feito, a saber, um estado de guerra constante. O tempo antigo figura então como "fundo virtual", de maneira análoga ao que diz Viveiros de Castro (2002) sobre o mito ameríndio, atentando para o fato de que ele é "indestrutível” e "inesgotável” e, por isso mesmo - parafraseando autor, o maracatu veio desse tempo, "mas não deve jamais (porque pode sempre) voltar a ele" (:419-420).

De toda forma, se o tempo antigo deixou de existir há tanto tempo a ponto de ninguém com quem conversei ter conseguido alcançá-lo em sua plenitude, é possível dizer também que ele permanece existindo a cada vez que o maracatu faz seus carnavais, sambadas, conversas e fantasias.

\section{Referências bibliográficas:}

CHAVES, Suiá Omim Arruda de Castro. Carnaval em Terras de Caboclo: uma Etnografia sobre Maracatus de Baque Solto. Dissertação de Mestrado. PPGAS/ Universidade Federal do Rio de Janeiro, Museu Nacional, 2008. 
- Carnaval em terras de caboclo: saber e "cultura" no maracatu de baque solto. Revista ENFOQUES, v.10, maio 2011.

. O brinquedo do princípio do mundo: música, dança e musicalidade no córrego do Machado (Nova Jequitinhonha). Tese de Doutorado. Departamento de Antropologia, Universidade de Brasília, 2013.

STOECKLI, Pedro. Sobre mestres e encantados: a jurema como expressão sentimental. Dissertação de Mestrado. Departamento de Antropologia, Universidade de Brasília, 2011.

SENA, José Roberto Feitosa de. Interpretando o ethos sagrado do maracatu rural cruzeiro do forte Recife/PE. Sociabilidades religiosas: mitos, ritos e identidades, XI Simpósio Nacional da Associação brasileira de História das Religiões. 2009

- Maracatus Rurais de Recife: entre a religiosidade popular e o espetáculo. Centro de Educação, Programa de Pós-Graduação em Ciências das Religiões, Universidade Federal da Paraíba, 2012.

Religiosidade popular no maracatu rural pernambucano: hibridismos, pluralidades e circularidades. Reunião Brasileira de Antropologia, 2014.

SUMAIA, Sévia. 'O caboclo velho, antigo, sabe brincar. Vai respeitar!': A diversidade dos rituais espirituais na brincadeira do maracatu de baque solto/rural. V Colóquio de História . Perspectivas históricas, historiografia, pesquisa e patrimônio. P. 543 - 556, 2011.

. Caboclo de lança: imaginário, identidade e narrativa social. Anais do XIII Congresso Brasileiro de Sociologia, 2007.

. 'O caboclo velho, antigo, sabe brincar. Vai respeitar!' A diversidades dos rituais espirituais na brincadeira do Maracatu Baque solto/rural. ITACOATIARA Uma revista Online de Cultura, Recife, ano 2, n 1, p. 62- 75, Abril 2012.

SILVA, Severino Vicente. Festa de Caboclo. Coleção Maracatus e maracatuzeiros, Vol. 1. Recife: Ed. Associação Reviva, 2005.

Criatividade e liberdade nos brinquedos da Mata Norte, PE. Apontamentos para uma palestra no Instituto Arqueológico, Histórico e Geográfico Pernambucano, 2010. 
VIVEIROS DE CASTRO, Eduardo. "Atualização e contra-efetuação do virtual: o processo do parentesco". In: A inconstância da alma selvagem - e outros ensaios de antropologia. São Paulo: Cosac \& Naify, 2002b. 